\title{
Unconventional vegetable oils as raw materials for biodiesel production
}

The aim of the study was to determine the possibility of using the unconventional vegetable oils for the biofuel production. The research material were cold-pressed oils from the seeds of milk thistle, hemp and evening primrose. After conducting the initial physicochemical characteristics of oil samples, including the determination of sulphur content, acid number, viscosity at $40^{\circ} \mathrm{C}$, density at $15^{\circ} \mathrm{C}$, oxidation stability and fatty acid composition, analysed oils have been subjected to the transesterification process. The produced methyl esters were further characterized by the above-mentioned features. Additionally, the temperatures of cold filter plugging point, cloud point and flash point were determined. On the basis of the conducted analyses it was demonstrated that the obtained oils, due to the high, far in excess of acceptable, values of the viscosity and density, and too low oxidative stability could not be used as a pure fuel. A similar conclusion was formulated in case of the produced methyl esters.

Key words: unconventional vegetable oils, quality, fatty acids composition, biofuels production

\section{Introduction}

Vegetable oils are widely used in the food, cosmetic, pharmaceutical, chemical industries, as good as in the fuel industry $[1,2]$. These products can be obtained from many kind of plant species, however the world consumption is dominated by the soybean, palm, rapeseed, and sunflower oils [3]. It is believed that only the plant seeds, that occurs abundant and are characterized by the high oil content of appropriate quality are feasible for the biodiesel production. One of the most important factor determining the choice of an individual plant is its location, include climate and feedstock availability. The rapeseed and sunflower oils are predominantly used in Europe, while the palm oil predominates in the tropical countries. In turn, the soybean oil and animal fats are used in the United States [4].

On the other hand, as Chung cited by Torrey, the conventional sources no longer meet the increasing demands of the domestic and industrial sectors [5]. Therefore, the need for searching the other raw materials is existed. The usefulness of vegetable oils as raw materials for the biodiesel production is conditioned, among others, the species and variety, yield of seed and fat, and energy efficiency indicators [6-8]. Among the unconventional vegetable oils are these pressed from the seeds of milk thistle, hemp and evening primrose, which are widely known from their beneficial health properties.

Generally, authors of the presented work found that using the raw materials, that are commonly used for the medical, pharmaceutical and nutritional purposes, should be reduced in fuel industry. However, it should be remembered that these plants may occur on a contaminated soil, where different weed infestations and numerous pests are observed, and therefore their usage in the mentioned sectors would not be possible.

The milk thistle (Silybum marianum L.) is well known medical herb that is popular in the European traditional medicine, especially using during the treatment of different liver diseases. One the other hand, in Maroko that plant is considered as weed, that is abundantly available and is suitable for the control of environment pollutants $[2,9,10]$.
The average oil content in that plant seeds ranges from 20 to $35 \%$, what is similar to many other vegetable oils [11].

The evening primrose (Oenothera biennis L.) oil (18$25 \%)$ is one of the most important health- promoting specialty oil, and is being used in increasing amounts in the nutritional and pharmaceutical preparations [12]. It is classified as a "dietary supplement" under the Dietary Supplement Health and Education Act of 1994. As "Chemical Information Review Document for Evening Primrose Oil (Oenothera biennis L.)" reported nowadays it is cultivated in over 30 countries for its oil [13].

The hemp oil is derived from the seeds of Cannabis sativa (ranged from 25 to $35 \%$ ) and contains significant amounts of the linolenic acid and linolenic acids $[14,15]$. The cultivation of that plant is legally in Canada as a niche crop and is used mainly in the health food market [16]. As Leizer et al. found the additional presence of gamma-linolenic acid (GLA) in the hemp oil ultimately makes its nutritional value superior to the most comparable seed oils [17].

Taking into account the above the aim of the presented work was to determine the possibility of use the unconvetional oils for the biofuels production.

\section{Material and analytical methods}

\subsection{Material}

The research material consisted of three samples of the commercial, cold-pressed oils from hemp, milk thistle and evening primrose seeds.

\subsection{Analytical methods}

The oil samples were characterized in terms of a viscosity at $40^{\circ} \mathrm{C}$ (PN-EN ISO 3104$)$, density at $15^{\circ} \mathrm{C}$ (PN-EN ISO 12185), acid value (PN-EN14104:2004P), oxidative stability (PN-EN ISO 6885:2016-04P) and fatty acids composition (PN-EN ISO 12966-4:2015-07E).

After conducting the physico-chemical characteristics of the oils the double-base transestrification process was carried out. In the first stage of reaction $200 \mathrm{~g}$ of oil was heated to $60^{\circ} \mathrm{C}$ and then a solution of potassium methoxide was 
added (by using methanol in a ratio of oil $=1: 6(\mathrm{v} / \mathrm{v})$ and $\mathrm{KOH}$ in an amount of $1 \%$ based on the weight of oil). The reaction was carried out in $60^{\circ} \mathrm{C}$ for $40 \mathrm{~min}$. In the first stage of process $3 / 4$ of the total amount of potassium methoxide was added and in second one $1 / 4$. Then the reaction mixture was subjected to the separation for $24 \mathrm{~h}$. After the complete separation, the upper ester phase was poured into glass flasks and the second stage of reaction was conducted in $60^{\circ} \mathrm{C}$ for $30 \mathrm{~min}$. After the second step of the transestrification the ester phase was isolated as described above.

The methyl esters obtained from different vegetable oils were determined in terms of the sulphur content (as above), acid value (ISO 14104), viscosity at $40^{\circ} \mathrm{C}$ (as above), the density at $15^{\circ} \mathrm{C}$ (as above), oxidative stability (ISO 14112), temperature of flash point (PN-EN ISO 3679) and temperature of cold point and the cold filter plugging point (EN 116).

\section{Results and discussion}

The obtained vegetable oils were characterized by the high values of the viscosity and density, however typical for the oils pressed from seeds of these plant species. The oil sample obtained from milk thistle seeds was characterized by the highest value of mentioned parameters (respectively, $59.54 \mathrm{~mm}^{2} / \mathrm{s}$ and $927 \mathrm{~kg} / \mathrm{m}^{3}$ ). In turn, lower, however similar, values were noticed for the samples of evening primrose and hemp oils. A similar tendency was observed in case of the acid value, that determines the hydrolysis degree (Table 1). The oil of milk thistle was the most hydrolysed, as indicated the increased values of acid value $(10.07 \mathrm{mh} \mathrm{KOH} / \mathrm{g})$ and \%FFA $(5.035 \%)$. The degree of hydrolysis of other two samples were lower, however approx. 2-fold higher that the recommended value $(<3 \mathrm{mg}$ $\mathrm{KOH} / \mathrm{g}$ ) [18]. The stated for all samples the high hydrolysis degree allowed to decide, which method of the transesterification (single, double) should be used. Taking into consideration a weak quality of oils and an economic aspect, authors of the presented work decided to use the doublebase transesterification.

The oxidative stability and fatty acids composition were typical for the oils pressed from seeds of these plant species [2, 13, 14, 19-21] (Table 1). The hemp oil, with high share of polyunsaturated acids (especially gamma linolenic), was characterized by the lowest resistance to the oxidation, while significantly higher the milk thistle oil, that was characterized by the highest share of saturated acids (palmitic, stearic, arachidic and behenic acids). It should be remembered that the fatty acids profile of raw materials does not change during the transesterification process [22], therefore, stated for the analysed samples low oxidative stability will be determined the low value of that discriminant for the produced methyl ester samples.

Table 1. Characterization of the analysed oils

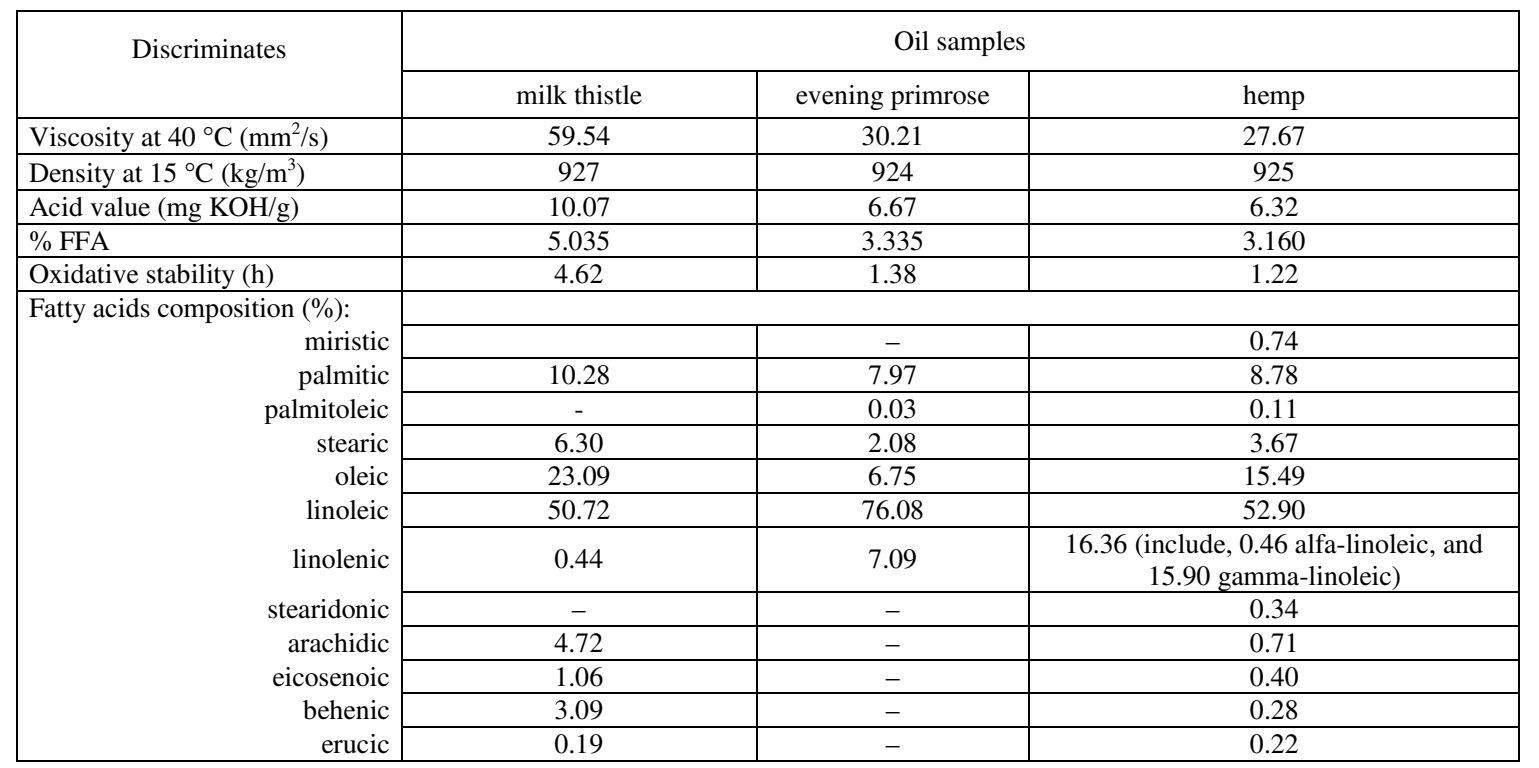

The transestrification process of the analysed oils significantly contributed to the reduction of the viscosity (approx. 6.5 -fold) and density values (Table 2), whereby two of samples (evening primrose and hemp oils) met the requirements of the UE standard EN 14214. On the other hand, the values of these parameters for the milk thistle oil significantly exceeded the required values. That sample was also characterized by the highest, and therefore unacceptable, values of the temperature of cloud point and temperature of cold filter plugging point, which could contribute to the hindered engine work in lower temperatures. What is more, all of the analysed ester samples were characterized by too low oxidative stability and too high values of acid value. The only features that fulfilled the standard requirements were the temperature of flash point $\left(>101^{\circ} \mathrm{C}\right)$ and sulphur content $(<10 \mathrm{ppm})$.

Sanford et al., analysing different unconventional sources for the biodiesel production, among others, oils from hemp and evening primrose seeds found similar results as these in presented work [23]. Additionally, the main features determined for the milk thistle biodiesel were almost on the same level, compared to these obtained by Ullah et al [24]. Moreover, Li et al., analysing the feasibility of converting Cannabis sativa L. oil into the biodiesel, 
also found that methyl esters of that sample were characterized by the suitable values of the viscosity, density, sulphur content and flash point [25]. However, as it was also stated, values of the cloud point and temperature of cold filter plugging were too high. What is more, in Alcheikh work, it is presented, that the biodiesel produced from hemp oil was also characterized by the poor oxidative stability [26].

Table 2. Characteristics of the prepared methyl esters

\begin{tabular}{|l|c|c|c|}
\hline \multirow{2}{*}{ Discriminants } & \multicolumn{3}{|c|}{$\begin{array}{c}\text { Methyl esters obtained from } \\
\text { different oils }\end{array}$} \\
\cline { 2 - 4 } & $\begin{array}{c}\text { milk } \\
\text { thistle }\end{array}$ & $\begin{array}{c}\text { evening } \\
\text { primrose }\end{array}$ & hemp \\
\hline Viscosity at $40^{\circ} \mathrm{C}\left[\mathrm{mm}^{2} / \mathrm{s}\right]$ & 8.87 & 4.67 & 3.92 \\
\hline Density at $15^{\circ} \mathrm{C}\left[\mathrm{kg} / \mathrm{m}^{3}\right]$ & 898 & 888 & 884 \\
\hline Flash point $\left[{ }^{\circ} \mathrm{C}\right]$ & $>160$ & $>160$ & $>160$ \\
\hline Cloud point $\left[{ }^{\circ} \mathrm{C}\right]$ & -5 & -4 & -6 \\
\hline Cold filter plugging point $\left[{ }^{\circ} \mathrm{C}\right]$ & -6 & -5 & -7 \\
\hline Acid value $[\mathrm{mg} \mathrm{KOH} / \mathrm{g}]$ & 0.32 & 0.66 & 1.11 \\
\hline Sulphur content $[\mathrm{ppm}]$ & 1.96 & 2.23 & 2.54 \\
\hline Oxidative stability $[\mathrm{h}]$ & 4.78 & 1.44 & 1.32 \\
\hline
\end{tabular}

Rizwanul Fattah et al. found, that mentioned features do not disqualify analysed oils as a raw material for the fuel purposes, because these discriminants may be easily improved with the chemical additives, such as antioxidants, that are commonly used to inhibit the oxidative degradation of biodiesel [27].

What is more, as Nwadike et al. found increased viscosity of biodiesel (in case of milk thistle biofuel) may be decrease by either blending with a conventional diesel oil or other biodiesel characterized by the lower share of saturated methyl esters [28].

\section{Conclusions}

Commonly used for the medical, pharmaceutical and nutritional purposes the hemp, milk thistle and evening primrose oils should not be generally used in the fuel industry, due to their beneficial health properties. One the other hand, in case of the possible deficiency of widely used oleic raw materials, such as rapeseed, sunflower and soybean, seeds of that plant species could be used to the methyl esters production. However, it should be remembered that an addition of different compounds, such as antioxidants, would be needed, due to the low oxidative stability of these oils, and therefore the produced methyl esters. What is more, in case of the milk thistle oil it would be necessary to prepare a blend with lees viscous diesel oil, because as a pure fuel characterized by too high viscosity it would not be suitable for the Diesel engines.

\section{Bibliography}

[1] DUGO, G., PERA, L., TORRE, G.L., GIUFFRIDA, D. Determination of $\mathrm{Cd}(\mathrm{II}), \mathrm{Cu}(\mathrm{II}), \mathrm{Pb}(\mathrm{II})$, and $\mathrm{Zn}$ (II) content in commercial vegetable oils using derivative potentiometric stripping analysis. Food Chemistry. 2004, 87, 639-645

[2] ISMAILI, S.A, HARKAR, H., GHARBY, S. et al. Chemical composition of two non-conventional oils in Morocco: Melia azadirachta and Silybum marianum (L.). Journal of Materials and Environmental Sciences. 2016, 7(6), 2208-2213.

[3] STEVENSON, D.G., ELLER, F.J., WANG L. et al. Oil and tocopherol content and composition of pumpkin seed oil in 12 cultivars. Journal of Agricultural Food Chemistry. 2007, 55, 4005-4013.

[4] KNOTHE, G., KRAHL, J., VAN GERPEN, J. The biodiesel handbook AOCS Press, Champaign, USA 2005.

[5] CHUNG, K-H. Transesterification of Camellia japonica and Vernicia fordii seed oils on alkali catalysts for biodiesel production. Journal of Industrial and Engineering Chemistry. 2010, 16(4), 506-509.

[6] HEIMANN, S. Aktualne problemy dotyczące badania odmian rzepaku na cele konsumpcyjne oraz biopaliw i makuchy. Forum producentów roślin zbożowych, kukurydzy i rzepaku. Polagra - Forum 2002, 47-52.

[7] JANKOWSKI, K., BUDZYŃSKI, W. Energy potential oilseed crops. Electronic Journal of Polish Agricultural Universities, Agronomy. 2003, 6(2).

[8] BUDZYŃSKI, W., BIELSKI, S. Surowce energetyczne pochodzenia rolniczego. Cz. 1. Biokomponenty paliw płynnych. Acta Scientarium Polonorum seria Agricultura. 2004, 3(2), 5-14.

[9] FRASCHINI, F., DEMARTINI, G., ESPOSTI, D. Pharmacology of silymarin. Clinical Drug Investigation. 2002, 22(1), 51-65.

[10] KURKIN, V.A. Saint-Mary thistle: a source of medicinals. Pharmaceutical Chemistry Journal. 2003, 37(4), 189-202.
[11] RAMASAMY, K., AGARWAL, R. Multitargeted therapy of cancer by Silymarin. Cancer Letters. 2008, 269, 352-362.

[12] CHRISTIE, W.W. The analysis of evening primrose oil. Industrial Crops and Products. 1999, 10, 73-83.

[13] Chemical Information Review Document for Evening Promrose (Oenotheta biennis L.) [CAS No. 90028-66-3]. 2009, 138.

[14] DEFERNE, J.L., PATE, D.W. Hemp seed oil: A source of valuable essential fatty acids. Journal of the International Hemp Association. 1996, 3(1), 4-7.

[15] Hemp Seed Oil, 22 October 2009, www.bulknaturaloils. com/plantoil/alphalinoleic/hempseedoil.html

[16] JESSEN, H. Hemp biodiesel: when the smoke clears." Biodiesel Magazine. February, 2007. www.biodieselmaga zine.com/articles/1434/hemp-biodiesel-when-the-smokeclears

[17] LEIZER, C., RIBNICKY, D., POULEV, A. et al. The composition of hemp seed oil and its potential as an important source of nutrition. Journal of Nutraceuticals, Functional \& Medical Foods. 2000, 2(4), 35-53.

[18] PN-90/R-66151. Rośliny przemysłowe oleiste. Ziarno rzepaku i rzepiku podwójnie ulepszonego.

[19] CALLOWAY, J.C., LAAKKONEN, T.T. Cultivation of Cannabis oil seed varieties in Finland. Journal of the International Hemp Association. 1996, 3(1), 32-34.

[20] ULUATA, S., ÖZDEMIR, N. Antioxidant activities and oxidative stabilities of some unconventional oilseeds. Journal of American Oil Chemistry Society. 2012, 89(4), 551559.

[21] PRESCHA, A., GRAJZER, M., DEDYK, M., GRAJETA, $\mathrm{H}$. The antioxidant activity and oxidative stability of coldpressed oils. Journal of American Oil Chemistry Society. 2014, 91(8), 1291-1301.

[22] RAMOS, M.J., FERNÁNDEZ, C.M., CASAS, A. et al. Influence of fatty acid composition of raw materials on biodiesel properties. Bioresource Technology. 2009, 100(1), 261-268. 
[23] SANFORD, S.D., WHITE, J.M., SHAH, P.S. et al. Feedstock and biodiesel characteristics report. 2009, 1-136. biodiesel.org/reports/20091117_gen-398.pdf.

[24] ULLAH, K., AHMAD, M., QIU, F. Assessing the experimental investigation of milk thistle oil for biodiesel production using base catalyzed transesterification. Energy. 2015, 89, 887-895.

[25] LI, S-Y., STUART, J.D., PARNAS, R.S. The feasibility of converting Cannabis sativa L. oil into biodiesel. Bioresource Technology. 2010, 101(21), 8457-8460.

[26] ALCHIKH, A. Advantages and challegnes of hemp biodiesel production: A comparison of hemp vs. other crops
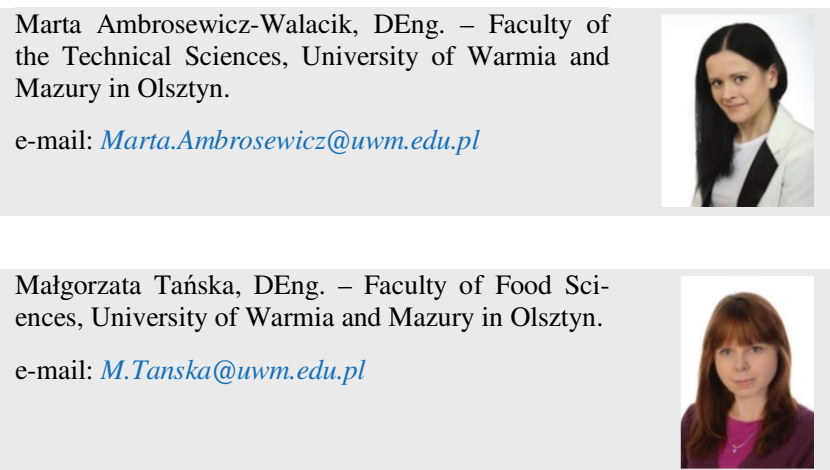

commonly used from biodiesel production. Master's Energy System, Faculty of Engineering ans Sustainable Development. University of Gävle, 2015, 1-31.

[27] RIZWANUL FATTAH, I. M., MASJUKI, H.H. et al. Effect of antioxidants on oxidation stability of biodiesel derived from vegetable and animal based feedstocks. Renewable \& Sustainable Energy Reviews. 2014, 30, 356-370.

[28] NWADIKE, I., YAHAYA, M., O'DONNELL, S. et al. Cold flow properties and kinematic viscosity of biodiesel. Universal Journal of Chemistry. 2013, 1(4), 135-141.
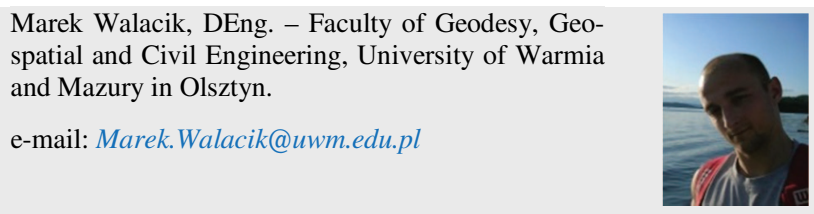

Michał Kozłowski, MSc. - Faculty of the Technical Sciences, University of Warmia and Mazury in Olsztyn.

e-mail: Michal.Kozłowski@uwm.edu.pl 